\title{
ANALISIS FAKTOR-FAKTOR YANG MEMPENGARUHI KEBIJAKAN PEMBAGIAN DEVIDEN PADA PERUSAHAAN FOOD AND BAVERAGES YANG LISTING DI BEI
}

\author{
NURAENI \\ Fakultas Sosial Ilmu Politik Universitas Yudharta Pasuruan \\ Email :noer_ryel@yahoo.co.id
}

\begin{abstract}
ABSTRAKSI
Penelitian ini bertujuan untuk memberikan bukti empiris mengenai faktor-faktor yang mempengaruhi keputusan pembagian dividen. Faktor-faktor yang di uji adalah struktur modal dan pertumbuhan perusahaan. Kedua faktor tersebut diukur dengan menggunakan rasio keuangan. Indikator penilaian struktur modal yang digunakan adalah rasio utang-ekuitas (debt to equity ratio) sedangkan indikator penilaian pertumbuhan perusahaan diukur dengan pertumbuhan aktiva. Sampel penelitian terdiri dari 13 dari 19 perusahaan food and beverage. Penentuan sampel tersebut berdasarkan metode purposive sampling. Sedangkan metode analisis yang digunakan untuk menguji hipotesis penelitian ini adalah regresi logistik. Hasil penelitian menunjukkan bahwa struktur modal dan pertumbuhan perusahaan memiliki daya prediksi untuk keputusan pembagian dividen. Penelitian ini juga memberikan bukti empiris bahwa hanya variabel pertumbuhan perusahaan yang secara statistik memberikan pengaruh yang signifikan untuk memprediksi keputusan pembagian dividen.
\end{abstract}

Kata Kunci: Struktur Modal, Pertumbuhan Perusahaan, Deviden

\section{PENDAHULUAN}

Pembagian dividen merupakan sebuah strategi yang dipergunakan oleh perusahaan agar harga saham perusahaan mengalami kenaikan. Karena, harga saham akan meningkat seiring kenaikan dividen. Artinya perusahaan cenderung meningkatkan pembayaran dividen, dengan harapan membaiknya nilai perusahaan dan dapat memaksimumkan harga saham di masa yang akan datang. Atau bisa dikatakan manajemen akan enggan untuk mengurangi pembagian dividen, kalau hal ini ditafsirkan dapat memperburuk kondisi perusahaan di masa yang akan datang,

sehingga akan menurunkan harga saham (Brigham dan Houston, 2006 :76).

Dividen mempunyai dampak pada harga saham karena dividen tersebut memberikan informasi atau isyarat tentang profitabilitas perusahaan. Pembayaran dividen yang stabil sepanjang waktu, kemudian perusahaan meningkatkan jumlah dividen yang dibayarkan, maka para investor percaya bahwa manajemen menunjukkan perubahan positif pada profitabilitas perusahaan yang diharapkan di waktu mendatang. Artinya dividen digunakan oleh para investor sebagai alat prediksi untuk prestasi perusahaan di masa 
mendatang, terutama untuk perusahaan go public. Tidak semua perusahaan yang menghasilkan laba positif dan bisa membagikan dividen kepada para pemegang saham. Beberapa alasan mendasar yang sering digunakan oleh perusahaan dalam memutuskan untuk tidak membagikan dividen. Pertama, keadaan perusahaan mengalami kesulitan keuangan yang serius sehingga tidak memungkinkan untuk membayar dividen. Pada saat kondisi demikian, perusahaan lebih memprioritaskan untuk memenuhi kewajiban (hutang) daripada membayar dividen. Kedua, adanya kebutuhan dana yang sangat besar karena investasi yang sangat menarik sehingga harus menahan seluruh pendapatan untuk membelanjai investasi tersebut. Alasan yang kedua ini merupakan asumsi yang mendasari teori "Dividen Residu", yakni dividen hanya dibayar jika laba tidak sepenuhnya digunakan untuk tujuan investasi, artinya hanya pada saat ada "pendapatan sisa" setelah pendanaan investasi baru (Keown, 2000 : 613-614). Kedua alasan tersebut sekaligus merupakan terjemahan dari dua faktor yang menjadi fokus perhatian peneliti diantara faktor-faktor lainnya yang dapat mempengaruhi keputusan pembagian dividen. Kedua faktor tersebut adalah struktur modal dan pertumbuhan perusahaan.

Kebijakan mengenai struktur modal melibatkan trade off antara risiko dan tingkat pengembalian, penambahan utang memperbesar risiko perusahaan tetapi sekaligus juga memperbesar tingkat pengembalian yang diharapkan. Risiko yang makin tinggi akibat membesarnya utang cenderung akan menurunkan harga saham, walaupun akan meningkatkan tingkat pengembalian yang diharapkan. hasil penelitian Darminto (2008:87) menunjukkan bahwa struktur modal berpengaruh secara signifikan terhadap kebijakan dividen.

Tingkat pertumbuhan perusahaan juga dapat dikatakan sebagai salah satu faktor yang mempengaruhi keputusan pembagian dividen karena, semakin cepat tingkat pertumbuhan suatu perusahaan, maka makin besar kebutuhan akan dana untuk membiayai pertumbuhannya, perusahaan tersebut biasanya lebih senang untuk menahan pendapatannya daripada dibayarkan sebagai dividen kepada para pemegang saham dengan mengingat batasan-batasan biayanya. Hal ini berarti bahwa makin cepat tingkat pertumbuhan perusahaan maka semakin besar kesempatan untuk memperoleh keuntungan, makin besar bagian dari pendapatan yang di tahan dalam perusahaan, yang ini berarti semakin rendah dividend payout ratio-nya (Riyanto, 2001: 267).

Peluang terbaginya dividen dapat diprediksi dengan beberapa indikator. Salah satu indikator yang digunakan adalah laporan keuangan perusahaan. Berdasarkan 
laporan keuangan perusahaan, akan dapat dihitung sejumlah rasio keuangan yang lazim dijadikan sebagai alat ukur beberapa faktor yang digunakan untuk memprediksi peluang terbaginya dividen. Penelitian ini bertujuan untuk memprediksi pengaruh struktur modal dan pertumbuhan perusahaan terhadap peluang pembagian dividen.

Berdasarkan uraian diatas dan beberapa penelitan sebelumnya dapat ditarik rumusan masalah sebagai berikut: (1) Adakah pengaruh struktur modal dan pertumbuhan perusahaan terhadap keputusan pembagian dividen pada perusahaan food and beverage?. (2)

Seberapa besar pengaruh struktur modal dan pertumbuhan perusahaan terhadap keputusan pembagian dividen pada perusahaan food and beverage?. (3) Diantara struktur modal dan pertumbuhan perusahaan, variabel manakah yang berpengaruh signifikan terhadap keputusan pembagian dividen pada perusahaan food and beverage?

\section{Landasan Teori}

\section{a. Struktur Modal}

Menurut Weston, et al. (1997), Struktur modal adalah pembiayaan pembelanjaan permanen perusahaan, khususnya berupa hutang jangka panjang, saham preferen/prioritas dan modal biasa, tetapi tidak termasuk semua kredit jangka pendek. Dengan kata lain, struktur modal adalah perimbangan seluruh modal yang dimiliki perusahaan dari berbagai sumber dana yang berbeda. Secara sederhana, struktur modal merupakan perbandingan antara jumlah hutang jangka panjang dan modal sendiri. Perbandingan antara hutang jangka panjang dengan modal sendiri disebut juga sebagai long-term debt to equity ratio atau leverage keuangan perusahaan. Sedangkan menurut Martono dan Harjito (2001 : 240-246), struktur modal adalah perbandingan atau imbangan pendanaan jangka panjang perusahaan yang ditunjukkan oleh perbandingan hutang jangka panjang terhadap modal sendiri. Pemenuhan kebutuhan dana perusahaan dari sumber modal sendiri berasal dari modal saham, laba ditahan dan cadangan. Jika dalam pendanaan perusahaan yang berasal dari modal sendiri masih mengalami kekurangan maka perlu dipertimbangkan pendanaan dari luar, yaitu hutang. Namun dalam pemenuhan kebutuhan dana, perusahaan harus mencari alternatifalternatif pendanaan yang efisien. Adapun Indikator struktur modal yang yang dipakai dalam adalah rasio utang-ekuitas (debt-toequity ratio). Rasio utang-ekuitas adalah perbandingan antara utang jangka panjang (long term debt) dengan ekuitas saham biasa (stock equity). Secara sistematis, rasio utang-ekuitas dapat diformulasikan sebagai berikut: 
RasioUtang-Ekuitas

\section{Utang Jangka Panjang}

Ekuitas Saham Biasa

\section{b. Pertumbuhan Perusahaan}

Pertumbuhan perusahaan yang cepat maka semakin besar kebutuhan dana untuk ekspansi. Semakin besar kebutuhan untuk pembiayaan mendatang maka semakin besar keinginan perusahaan untuk menahan laba. Jadi perusahaan yang sedang tumbuh sebaiknya tidak membagikan laba sebagai dividen tetapi lebih baik digunakan untuk ekspansi. Potensi pertumbuhan ini dapat diukur dari besarnya biaya penelitian dan pengembangan. Semakin besar R\&D costnya maka berarti ada prospek perusahaan untuk tumbuh (Sartono, 2001:248).

Pertumbuhan perusahaan dapat diukur dengan dua indikator. Indikator pertama yakni pertumbuhan penjualan (Putera, 2011:51). Pengukuran ini hanya dapat melihat pertumbuhan perusahaan dari aspek pemasaran perusahaan saja. Indiktor kedua adalah pertumbuhan total asset perusahaan (Jannati, 2012:5). Pertumbuhan total asset perusahaan adalah selisih antara total asset tahun sekarang dengan total asset tahun sebelumnya dibagi dengan total asset tahun sebelumnya.

\section{c. Deviden}

Riyanto (2001:265) menyatakan pengertian dividen adalah sebagai berikut :
"Dividen adalah aliran kas yang dibayarkan kepada para pemegang saham atau equity investors".

Dividen merupakan sesuatu yang memberatkan bagi perusahaan yang membayarnya karena perusahaan harus selalu menyediakan sejumlah kas dalam jumlah yang relatif permanen untuk membayar dividen di masa mendatang. Disamping itu pembayaran dividen juga mengurangi kesempatan perusahaan untuk menjalankan investasi yang menghasilkan NPV positif.

Menurut Fakhruddin (2008:195), bentuk dividen yang dibayarkan dapat dibedakan atas:

1) Dividen tunai (Cash Dividend) adalah dividen yang dibagi kepada pemegang saham dalam bentuk kas (tunai).

2) Dividen saham (Stock Dividend) adalah dividen yang dibagi bukan dalam bentuk tunai melainkan dalam bentuk saham perusahaan tersebut.

3) Dividen properti (Property Dividend) adalah dividen yang dibagikan dalam bentuk aktiva lain selain kas atau saham, misalnya aktiva tetap dan surat-surat berharga.

4) Dividen likuidasi (Liquiditing dividend) adalah dividen yang diberikan kepada pemegang saham sebagai akibat dilikuidasinya perusahaan. Dividen yang dibagikan adalah selisih nilai realisasi aset 
perusahaan dikurangi dengan semua kewajibannya.

\section{Keputusan Pembagian Deviden}

Keputusan pembagian dividen yang dimaksud dalam penelitian ini adalah keputusan yang di ambil oleh manajer keuangan untuk membagikan atau tidak membagikan dividen kepada para pemegang saham, dengan mempertimbangkan berbagai macam faktor yang terkait.

\section{METODE PENELITIAN}

Metode dan pendekatan penelitian ini adalah deskriptif kuantitatif. Tujuan dari penelitian deskriptif adalah untuk pemecahan masalah secara sistematis dan faktual mengenai fakta-fakta dan sifat populasi. Penelitian ini termasuk pendekatan kuantitatif karena banyak menggunakan angka-angka mulai dari pengumpulan data, penafsiran terhadap data serta penampilan dari hasil pengolahan data tersebut (Arikunto, 2002:10).

\section{a. Populasi dan sampel}

Populasi dalam penelitian ini adalah semua perusahaan food and beverage yang terdaftar di Bursa Efek Indonesia (BEI). Adapun kriteria perusahaan yang akan menjadi sampel pada penelitian ini adalah sebagai berikut:

1) Mempublikasikan laporan keuangan yang telah diaudit setiap tahun selama periode 2009-2011.

2) Menghasilkan laba positif selama 3 tahun berturut-turut.

3) Membagikan dividen dalam tiga periode terakhir (tahun 2009-2011).

Berdasarkan kriteria sampel yang telah ditentukan, terdapat 13 perusahaan dari 19 perusahaan food and beverage yang memenuhi kriteria, sehingga dijadikan sampel dalam penelitian ini. Adapun sampel penelitian ini adalah:

Tabel 1. Sampel Penelitian

\begin{tabular}{|l|l|l|}
\hline No & Nama Perusahaan & $\begin{array}{l}\text { Kode } \\
\text { Perusahaan }\end{array}$ \\
\hline 1. & PT Cahaya Kalbar Tbk & CEKA \\
\hline 2. & PT Delta Djakarta Tbk & DLTA \\
\hline 3. & PT Fast Food Indonesia Tbk & FAST \\
\hline 4. & PT Indofood CBP Sukses Makmur & ICBP \\
\hline 5. & PT Indofood Sukses Makmur Tbk & INDF \\
\hline 6. & PT Multi Bintang Indonesia Tbk & MLBI \\
\hline 7. & PT Mayora Indah Tbk & MYOR \\
\hline 8. & PT Prasidha Aneka Niaga Tbk & PSDN \\
\hline 9. & PT Nippon Indosari Corpindo Tbk & ROTI \\
\hline 10. & PT Sierad Produce Tbk & SIPD \\
\hline 11. & PT Sinar Mas Agro Resources Technology Tbk & SMAR \\
\hline 12. & PT Tunas Baru Lampung Tbk & TBLA \\
\hline 13. & PT Ultrajaya Milk Industry dan Trading Company Tbk & ULTJ \\
\hline
\end{tabular}




\section{b. Deskripsi Operasional Variabel}

\section{Variabel Terikat (Y)}

Variabel dependen dalam penelitian ini merupakan variabel kualitatif. Yaitu keputusan pembagian deviden. Menurut Suliyanto (2011:167) variabel kualitatif merupakan variabel yang dinyatakan dalam bentuk pernyataan atau judgement. Untuk mengkuantitasikan variabel ini dilakukan dengan membangun variabel buatan (dummy/binary variable) yang mengambil nilai 1 dan 0 , dimana nilai 1 menunjukkan kehadiran (presence) variabel tersebut yakni dividen dibagikan kepada para pemegang saham, sedangkan 0 menunjukkan ketidakhadiran (absence) variabel tersebut yakni dividen tidak dibagikan kepada para pemegang saham.

\section{Variabel Bebas $(\mathbf{X})$}

\section{a. Struktur Modal $\left(\mathbf{X}_{1}\right)$}

Variabel struktur modal dalam penelitian ini diukur dengan rasio utangekuitas (debt-to-equity ratio). Rasio utang-ekuitas adalah perbandingan antara utang jangka panjang (long term debt) dengan ekuitas saham biasa (stock equity). Rasio utang-ekuitas inilah yang lebih sering digunakan sebagai indikator struktur modal, baik oleh teoritisi maupun praktisi (Warsono, 2003:239).

\section{b. Pertumbuhan Perusahaan $\left(\mathbf{X}_{2}\right)$}

Indikator pertumbuhan perusahaan dalam penelitian ini adalah tingkat pertumbuhan aktiva. Indikator ini sebagaimana digunakan oleh Jannati (2012:5) untuk mencerminkan tingkat pertumbuhan perusahaan dalam penelitiannya yang berjudul "pengaruh profitabilitas, leverage dan growth terhadap kebijakan dividen". Berikut rumus tingkat pertumbuhan aktiva:

$$
\begin{aligned}
& \text { Pertumbuhan perusahaan }= \\
& \frac{\text { Total Aktiva }_{\mathrm{t}}-\text { Total Aktiva }_{\mathrm{t}-1}}{\text { Total Aktiva }_{\mathrm{t}-1}}
\end{aligned}
$$

\section{c. Teknik Analisa Data}

Teknik analisis data yang digunakan dalam penelitian ini adalah analisis regresi logit. Menurut Gujarati (2012:188) model Logit dapat dituliskan sebagai berikut:

$$
L_{i}=l_{n}\left(\frac{P_{i}}{1-P_{i}}\right)=\beta_{0}+\beta_{2} X i
$$

Berdasarkan model logit tersebut, maka model logit dalam penelitian ini adalah sebagai berikut:

$$
L_{i}=l_{n}\left(\frac{P_{i}}{1-P_{i}}\right)=\beta_{1}+\beta_{2} \mathrm{DER}+\beta_{3}
$$

Tingkat Pertumbuhan Aktiva

\section{Keterangan:}

p adalah probabilitas kejadian dari variabel terikat $(\mathrm{Y})$

$\mathrm{p} \quad=1$; Dividen dibagikan kepada para pemegang saham 
$\mathrm{p} \quad=0 \quad ;$ Dividen tidak dibagikan kepada para pemegang saham

$\beta_{1} \quad=$ Konstanta

$\beta_{2} \quad=$ Koefisien DER

$\beta_{3}=$ Koefisien Tingkat

Pertumbuhan Aktiva

DER = Debt to Equity Ratio

\section{d. Pengujian Signifikansi Model dan}

\section{Parameter}

1. Uji G atau Uji Keseluruhan Model (Overall Model Fit)

Analisis pertama yang dilakukan adalah menilai keseluruhan kelayakan model uji terhadap data. Pengujian ini dilakukan untuk mengetahui apakah kelayakan model uji dengan data baik sebelum maupun sesudah variabel bebas dimasukkan kedalam model.

$\mathrm{H}_{0}: \beta_{1}=\beta_{2}=\ldots \ldots .=\beta_{\mathrm{p}}=0$

$\mathrm{H}_{1}$ : sekurang - kurangnya terdapat satu $\beta_{\mathrm{j}} \neq$ 0

Statistik uji yang digunakan:

$\mathrm{G}=-2 \ln \left[\frac{\text { likelihood }(\text { Model B })}{\text { likelihood }(\operatorname{Model} \mathrm{A})}\right]$

Model B : model yang hanya terdiri dari konstanta saja

Model A : model yang terdiri dari seluruh variabel

$\mathrm{G}$ berdistribusi Khi Kuadrat dengan derajat bebas p atau $\mathrm{G} \sim \chi^{2} \mathrm{p}^{2} \cdot \mathrm{H}_{0}$ ditolak jika $\mathrm{G}>$ $\chi_{\alpha, p}^{2} ; \alpha$ : tingkat signifikansi. Bila $\mathrm{H}_{0}$ ditolak, artinya model A signifikan pada tingkat signifikansi $\quad \alpha \quad$ (Nachrowi, 2002:260).

\section{Uji Kelayakan Model Regresi} (Goodness of fit test)

Uji kelayakan model regresi (Goodness of fit test) hampir sama dengan $R$-Square dalam regresi linear berganda, yang menunjukkan seberapa besar semua variabel independen secara bersama-sama dalam mempengaruhi variabilitas variabel dependen. Uji ini digunakan untuk mengetahui ukuran ketepatan model yang dipakai. Alat ukur yang digunakan dalam uji ini adalah Nagelkerke's $R$ Square (Ghozali, 2005).

\section{Uji Wald: Uji signifikansi tiap-tiap parameter}

Uji wald digunakan untuk mengukur parameter yang digunakan apakah signifikan atau tidak signifikan secara statistik pada tingkat signifikansi $\alpha$ $=5 \%$.

$\mathrm{H}_{0}: \beta_{\mathrm{j}}=0$ untuk suatu $\mathrm{j}$ tertentu; $\mathrm{j}=$ $0,1, \ldots \ldots, \mathrm{p}$.

$\mathrm{H}_{1}: \beta_{\mathrm{j}} \neq 0$

Statistik Uji yang digunakan adalah:

$$
W_{j}=\left[\frac{\beta_{j}}{S E\left(\beta_{j}\right)}\right]^{2}
$$

Statistik ini berdistribusi Chi kuadrat dengan derajat bebas 1 atau secara simbolis ditulis $\mathrm{W}_{\mathrm{j}} \sim \chi_{1}^{2} . \mathrm{H}_{0}$ ditolak jika $\mathrm{W}_{\mathrm{j}}$ $>\chi^{2} \alpha, 1$; dengan $\alpha$ adalah tingkat 
signifikansi yang dipilih. Bila $\mathrm{H}_{0}$ ditolak, artinya parameter tersebut signifikan secara statistik pada tingkat signifikansi $\alpha$ (Nachrowi, 2002:261).

\section{Uji Tingkat Signifikansi}

Untuk menguji koefisien regresi dapat juga dengan melihat angka signifikansi (Santoso, 2004:74). Pengujian hipotesisnya dilakukan dengan cara membandingkan tingkat signifikansi dengan nilai $\alpha$ yang dipilih. Dasar pengambilan keputusannya adalah dengan nilai signifikansi secara statistik pada masing-masing variabel independen, dengan $\alpha$ tingkat signifikansi yang dipilih.

* Jika Sig. < $\alpha$, maka variabel independen tersebut benar-

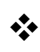

* benar berpengaruh terhadap variabel dependen, begitu juga sebaliknya.

* Jika Sig. > $\alpha$, maka variabel independen tersebut tidak berpengaruh terhadap variabel dependen.

\section{HASIL DAN PEMBAHASAN}

\section{a. Analisis Regresi Logistik}

Analisis statistik inferensial digunakan untuk pengujian hipotesis yang diajukan. Pengujian hipotesis dalam penelitian ini dengan menggunakan model regresi logistik. Regresi logistik adalah regresi yang digunakan untuk menguji apakah probabilitas terjadinya variabel terikat dapat diprediksi dengan variabel bebasnya (Ghozali, 2006:71). Regresi logistik digunakan untuk menguji apakah terdapat pengaruh yang signifikan dari pertumbuhan perusahaan dan DER terhadap keputusan pembagian dividen pada perusahaan Food and Beverage yang terdaftar di Bursa Efek Indonesia (BEI) periode 2009-2011. Pengujian dilakukan pada tingkat signifikasi $(\alpha) 5 \%$. Adapun hasil analisis menggunakan teknik Binary Logistic Regression adalah sebagai berikut: Model yang terbentuk dari hasil analisis regresi logistik pada tabel 3 adalah:

$$
\operatorname{Ln} \frac{P}{1-P}=1.077+-1302 \mathrm{X} 1+17.199
$$

$\mathrm{X} 2$

Berdasarkan model persamaan diatas, diperoleh nilai marginal effect sebagai berikut:

Tabel 2 Nilai Marginal Effect

\begin{tabular}{|l|l|}
\hline $\begin{array}{l}\text { Variabel } \\
\text { Independen }\end{array}$ & $\begin{array}{l}\text { Marginal } \\
\text { Effect }\end{array}$ \\
\hline $\begin{array}{l}\text { Struktur Modal } \\
(\mathrm{X} 1)\end{array}$ & -0.331 \\
\hline $\begin{array}{l}\text { Pertumbuhan } \\
\text { Perusahaan (X2) }\end{array}$ & 4.368 \\
\hline
\end{tabular}


Tabel 3 Hasil analisis Binary Logistic Regression

\begin{tabular}{|c|c|c|c|c|}
\hline Variabel & $\begin{array}{c}\text { Koefisien } \\
(\boldsymbol{\beta})\end{array}$ & Wald & $\begin{array}{c}\text { Prob } \\
(\mathbf{S i g}, \boldsymbol{\alpha}=\mathbf{5 \%} \%)\end{array}$ & Keterangan \\
\hline $\begin{array}{c}\text { Struktur } \\
\text { Modal (X1) }\end{array}$ & -1.302 & 1.428 & 0.232 & $\begin{array}{c}\text { Tidak } \\
\text { Signifikan }\end{array}$ \\
\hline $\begin{array}{c}\text { Pertumbuhan } \\
\text { Perusahaan } \\
(\mathrm{X} 2)\end{array}$ & 17.199 & 6.833 & 0.009 & Signifikan \\
\hline Konstanta & 1.077 & 0.884 & 0.347 & \\
\hline
\end{tabular}

Berdasarkan tabel 2 dan 3 di atas dapat ditarik kesimpulan bahwa:

a. Konstanta

Persamaan menunjukkan bahwa nilai intersep $=1.077$. Artinya: $\ln \left(\frac{p}{1-p}\right)=$ 1.077, pada saat kedua variabel yaitu struktur modal dan pertumbuhan perusahaan sama dengan nol. Dengan demikian, besaran $\left(\frac{p}{1-p}\right)=\mathrm{e}^{1.077}$ atau besarnya kemungkinan (peluang) $p=$ $\frac{e^{1.077}}{1+e^{1.077}}=0.75$.

Dengan perkataan lain, peluang terbaginya dividen pada saat struktur modal dan pertumbuhan perusahaan sama dengan nol adalah sebesar 0.75 atau $75 \%$.

b. Struktur Modal

$$
\text { Variabel struktur modal }
$$
mempunyai pengaruh negatif terhadap keputusan pembagian dividen. Hal ini dapat dilihat dari nilai marginal effect sebesar 0.331 , artinya setiap peningkatan struktur modal maka akan berdampak pada penurunan probabilitas terbaginya dividen sebesar -0.331, dengan kata lain semakin tinggi struktur modal maka semakin rendah probabilitas terbaginya dividen. Variabel ini tidak mempunyai pengaruh yang signifikan terhadap keputusan pembagian dividen. Hal ini terbukti dengan nilai statistik wald lebih kecil daripada nilai $\chi^{2}$ pada tabel $(1.428<$ 3.841).

c. Pertumbuhan Perusahaan

Variabel pertumbuhan perusahaan mempunyai pengaruh positif terhadap keputusan pembagian dividen. Hal ini dapat dilihat dari nilai marginal effect sebesar 4.368, artinya setiap peningkatan pertumbuhan perusahaan maka akan meningkatkan probabilitas terbaginya dividen sebesar 4.368, dengan kata lain semakin tinggi tingkat pertumbuhan perusahaan maka semakin tinggi pula probabilitas terbaginya dividen. Variabel ini mempunyai pengaruh yang signifikan terhadap keputusan pembagian dividen. Hal ini terbukti dengan nilai statistik wald lebih besar daripada nilai $\chi^{2}$ pada tabel $(6.833>$ $3.841)$. 


\section{b. Uji Analisis Regresi Logistik}

\section{Uji $G$ atau Uji Keseluruhan} Model (Overall Model Fit)

Hasil uji kelayakan model uji logistik dapat dilihat pada tabel berikut:

Tabel 4 Hasil Uji Keseluruhan Model

\begin{tabular}{|l|l|}
\hline Block & -2 Log \\
Number & Likelihood \\
\hline 0 & 42.136 \\
1 & 21.794 \\
\hline
\end{tabular}

Sumber : Hasil pengolahan data dengan SPSS

Berdasarkan tabel 4 diatas menunjukkan nilai -2 Log Likelihood (2LL) pada (Block Number $=0$ ) adalah 42.136, kemudian terjadi penurunan nilai -2 Log Likelihood (-2LL) pada (Block Number =1) menjadi 21.794, maka dapat ditarik kesimpulan bahwa model tersebut menunjukkan model regresi yang baik.

Nilai uji keseluruhan model juga bisa diperoleh dengan membandingkan antara nilai -2 Log Likelihood (-2LL) pada (Block Number $=1$ ) dengan nilai $\chi^{2}$ pada tabel $(21.794>3.841)$. Sehingga Ho ditolak dan Ha diterima, artinya semua variabel bisa dimasukkan ke dalam tabel (sekurang-kurangnya $\beta_{\mathrm{j}} \neq 0$ ).

\section{Uji Kelayakan Model Regresi} (Goodness of fit)

Tabel 5 Hasil Uji Kelayakan Model

\begin{tabular}{|c|c|c|c|c|}
\hline & Regresi & & & sebesar 1.428 yakni lebih kecil dari 3.841 . \\
\hline Keterangan & $\begin{array}{l}2 \text { Log } \\
\text { Likelihood }\end{array}$ & $\begin{array}{l}\text { Cox \& } \\
\text { Snell } \\
R \\
\text { Square } \\
\end{array}$ & $\begin{array}{l}\text { Nagelkerke } \\
R \text { Square } \\
1\end{array}$ & $\begin{array}{l}\text { Artinya Ho diterima, dengan kata lain } \\
\text { parameter variabel struktur modal tidak }\end{array}$ \\
\hline 1 & 21.794 & 0.406 & 0.615 & Stgnifikan secara statistik pada tingkat \\
\hline
\end{tabular}

Tabel 5 menunjukkan nilai Nagelkerke R Square. Hasil output pengolahan data nilai Nagelkerke $R$ Square adalah sebesar 0.615 . Hal ini menunjukkan bahwa keputusan pembagian dividen yang dapat dijelaskan oleh struktur modal dan pertumbuhan perusahaan adalah sebesar 61,5\%, sisanya sebesar $38.5 \%$ dijelaskan oleh variabel lain di luar model penelitian. Atau secara bersama-sama variabel struktur modal dan pertumbuhan perusahaan dapat menjelaskan variabel keputusan pembagian dividen sebesar $61,5 \%$.

\section{Uji Wald}

Tabel 6 Hasil Uji Wald

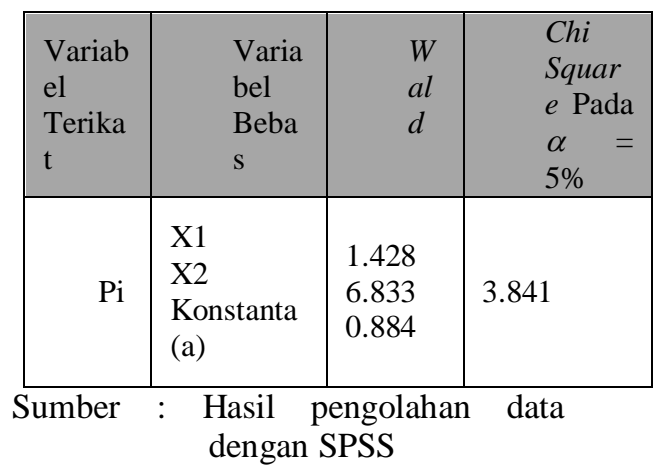

Tabel 6 menunjukkan bahwa nilai statistik wald variabel struktur modal . 
perusahaan sebesar 6.833 yakni lebih besar dari 3.841. Artinya Ho ditolak, dengan kata lain parameter variabel struktur modal tidak signifikan secara statistik pada tingkat signifikansi $\alpha=5 \%$.

\section{KESIMPULAN}

Berdasarkan hasil analisis regresi logistik, variabel struktur modal yang di ukur dengan debt to equity ratio mempunyai pengaruh negatif terhadap keputusan pembagian dividen. Hasil penelitian ini sejalan dengan penelitian Artini dan Puspaningsih (2011:72) yang menyatakan bahwa struktur modal tidak berpengaruh terhadap keputusan pembagian dividen. Hal ini menunjukkan bahwa tinggi rendahnya struktur modal perusahaan tidak mempengaruhi peluang pembagian dividen. Sedangkan pertumbuhan perusahaan berdasarkan hasil pengolahan data dapat diketahui bahwa variabel pertumbuhan perusahaan mempunyai pengaruh positif terhadap keputusan pembagian dividen. Hasil penelitian ini mendukung penelitian Jannati (2012:11) yang menyatakan bahwa pertumbuhan perusahaan berpengaruh terhadap keputusan pembagian dividen. Hal ini menunjukkan bahwa tinggi rendahnya tingkat pertumbuhan perusahaan dapat mempengaruhi peluang pembagian dividen.

\section{DAFTAR PUSTAKA}

Almilia, Luciana Spica dan Herdiningtyas, Winny. 2005. Analisis Rasio CAMEL Terhadap Prediksi Kondisi Bermasalah pada Lembaga Perbankan Periode 2000-2002. Jurnal Akuntansi dan Keuangan. Vol.7, No.2, November 2005.

Artini, Luh Gede Sri dan Puspaningsih, Ni Luh Anik. 2010. "Struktur Kepemilikan dan Struktur Modal terhadap Kebijakan Dividen dan Nilai Perusahaan", Jurnal Keuangan dan Perbankan. Vol.15, No.1, Januari 2011, hlm. 66-75.

Arikunto, Suharsimi. Prosedur Penelitian : Suatu Pendekatan Praktek. Jakarta: PT Rineka Cipta. 2002.

Baridwan, Zaki. Intermediate Accounting, Edisi kedelapan. Yogyakarta : BPFE, 2004.

Brigham, Eugene F dan Houston, Joul F. Dasar-dasar manajemen Keuangan Edisi ke-10. Jakarta : Salemba Empat, 2006.

Darminto. 2008. "Pengaruh Profitabilitas, Likuiditas, Struktur Modal dan Struktur Kepemilikan Saham terhadap Kebijakan Dividen", Jurnal Ilmu-ilmu Sosial. Vol. 20, No.2, Agustus 2008.

Fakhruddin, Hendy M. GO PUBLIC: Strategi Pendanaan dan Peningkatan Nilai Perusahaan. Jakarta: PT. Elex Media Komputindo, 2008.

G. Sugiyarso dan F. Winarni. Manajemen Keuangan ; Pemahaman Laporan Keuangan, Pengelolaan Aktiva, Kewajiban \& Modal, Serta Pengukuran Kinerja Perusahaan. Yogyakarta : Media Pressindo, 2005. 
Ghozali, Imam. Aplikasi Analisis Multivariat dengan Program SPSS, Edisi Ketiga. Semarang : Badan Penerbit Universitas Diponegoro, 2005.

Gujarati, Damodar dan Porter, Dawn. C. Dasar-dasar Ekonometrika. Jakarta : Salemba Empat, 2012.

Hanafi, Mamduh M. Manajemen Keuangan. Yogyakarta : BPFEYOGYAKARTA, 2004.

Hardiatmo, Budi dan Daljono. 2013. "Analisis Faktor-Faktor yang Mempengaruhi Kebijakan Dividen (Studi Empiris Perusahaan Manufaktur yang Listing di Bursa Efek Indonesia Periode 20082010)", Jurnal Akuntansi. Vol.2, No. 1, Hal 1-13.

Hermawan, Asep. Penelitian Bisnis Paradigma Kuantitatif. Jakarta : PT. Grasindo, 2005.

Jannati, Attina. Pengaruh Profitabilitas, Leverage dan Growth terhadap Kebijakan Dividen.(Sensus pada Perusahaan Manufaktur Consumer Goods Industri yang listing di Bursa Efek Indonesia). Skripsi. Jurusan Akuntansi, Fakultas Ekonomi, Universitas Siliwangi. 2012.

Jogiyanto. Teori Portofolio dan Analisis Investasi, Edisi ketujuh. Yogyakarta : $\quad$ BPFEYOGYAKARTA, 2010.

Keown, Arthur J; David F dan Marthin; John D dan Petty, Jay W. Dasardasar Manajemen Keuangan. Jakarta : Salemba Empat, 2000.

Komputer, Wahana. Solusi Mudah Dan Cepat Menguasai SPSS 17.0 Untuk Pengolahan Data Statistik. Jakarta : PT. Elex Mdia Komputindo, 2009.
Lubis, Irwansyah. Menggali Potensi Pajak Perusahaan dan Bisnis dengan Pelaksanaan Hukum. Jakarta : PT. Elex Media, 2010.

Martono, Agus Harjito. Manajemen Perkreditan. Jakarta: Bumi Aksara, 2001.

Nachrowi, Djalal dan Usman, Hardius. Penggunaan Teknik Ekonometrika. Jakarta: Raja Grafindo Persada, 2002.

Narbuko, Cholid dan Achmadi, Abu. Metodologi Penelitian. Jakarta : Bumi Aksara, 2003.

Purnomo, Budi dan Perajaka, Maxi A. Awas Jangan Sampai Modar Di Pasar Modal; Strategi dan Kiat Sukses Berinvestasi Di Bursa Saham. Jakarta : Trans Media, 2008.

Putera, Cendekia Septabaskara. Analisis Faktor-faktor Yang Berpengaruh terhadap Dividend Payout Ratio (Pada Perusahaan Manufaktur Periode 2006-2008). Skripsi. Jurusan Manajemen Keuangan, Fakultas Ekonomi Universitas Diponegoro, Semarang. 2011.

Riyanto, Bambang. Dasar-dasar Pembelanjaan Perusahaan. Yogyakarta: BPFEYOGYAKARTA, 2001.

Santoso, Singgih. Statistik Multavariat. Jakarta : PT Elex Media Komputindo, 2010.

Sartono, Agus. Manajemen Keuangan Teori dan Aplikasi. Yogyakarta : BPFE-YOGYAKARTA, 2001.

Sawir, Agnes. Kebijakan Pendanaan dan Restrukturisasi Perusahaan. Jakarta : PT. Gramedia Pustaka Utama Jakarta, 2004. 
Siagian, Dergibso dan Sugiarto. Metode Statistika Untuk Bisnis dan Ekonomi. Jakarta: PT gramedia Pustaka Utama, 2000.

Sugiono, Arief. Manajemen Keuangan. Jakarta : PT. Gramedia Widiasarana Indonesia, 2009.

Suliyanto. Ekonometrika Terapan; Teori \& Aplikasi dengan SPSS. Yogyakarta : ANDI, 2011.

Sumarni, Murni dan Wahyuni, Salamah. Metodologi Penelitian Bisnis. Yogyakarta : ANDI, 2006.

Van Horne, James C dan Wachowicz JR, John M. Prinsip-prinsip Manajemen Keuangan. Jakarta : Salemba Empat, 2010.

Warsono. Manajemen Keuangan Perusahaan. Malang : Bayumedia Publishing, 2003.

Weston J. Fred dan Thomas E. Copeland. 1997. Manajemen Keuangan, jilid Dua. Edisi Sembilan. Binarupa Aksara. Jakarta. 